\title{
CYTOPATHOLOGICAL CHARACTERIZATION OF Mal de Río Cuarto virus IN CORN, WHEAT AND BARLEY
}

\author{
JOEL D. ARNEODO ${ }^{1}$, EUGENIA LORENZO², IRMA G. LAGUNA ${ }^{1}$, \\ GUILLERMINA ABDALA ${ }^{2}$ \& GRACIELA A. TRUOL ${ }^{1}$
}

${ }^{1}$ INTA-IFFIVE, Camino 60 cuadras, km 51ำ, 5119 Córdoba, Argentina, e-mail: gtruol@ correo.inta.gov.ar; ${ }^{2}$ Departamento de Ciencias Naturales, Facultad de Ciencias Exactas, Físico-Químicas y Naturales, Universidad Nacional de Río Cuarto,

Ruta 36, km 601, Río Cuarto, Córdoba, Argentina, e-mail: elorenzo@exa.unrc.edu.ar

(Accepted for publication 01/03/2002)

Corresponding author: Graciela A. Truol

ARNEODO, J.D., LORENZO, E., LAGUNA, I.G., ABDALA, G. \& TRUOL, G.A. Cytopathological characterization of Mal de Rio Cuarto virus in corn, wheat and barley. Fitopatologia Brasileira 27:298-302. 2002.

\begin{abstract}
The Mal de Río Cuarto disease is caused by Mal de Río Cuarto virus (MRCV) transmitted by Delphacodes kuscheli. Comparative studies were carried out on the cytopathological alterations produced by MRCV in corn (Zea mays), wheat (Triticum aestivum) and barley (Hordeum vulgare), as seen with a transmission electron microscope. Corn plants were infected with viruliferous $D$. kuscheli collected from the endemic disease area (i.e. Río Cuarto County, Córdoba, Argentina). For the viral transmission to small grain cereal plants, laboratory rared insects were used. In this case, the inoculum source was wheat and barley plants infected with MRCV isolate grown in a greenhouse. Leaf samples with conspicuous symptoms were collected: enations and size reduction in corn; crenatures, swelling veins and dark green color in small grain cereals. Viral infection was corroborated by

DAS-ELISA. Viroplasms containing complete and incomplete virus particles and fibrillar material were found in the cytoplasm of infected cells in all species. Mature virions were between 60 and $70 \mathrm{~nm}$ diameter. In wheat and barley, viroplasms and dispersed particles were observed only in phloem, while in corn virions were also found in cells of the bundle sheath. Crystalline arrays of particles were detected in corn enation constitutive cells. Tubular inclusions were found only in wheat samples. The three species showed abnormalities in the chloroplasts of affected cells. The results showed that MRCV cytopathology has similarities with other viruses from the genus Fijivirus, family family Reoviridae, but slight differences depending upon the host plant.

Additional keywords: virus characterization, electron microscopy, Fijivirus, Reoviridae, cereals.

\section{RESUMEN \\ Caracterización citopatológica del Mal de Río Cuarto virus en maíz, trigo y cebada}

La enfermedad denominada mal de Río Cuarto es causada por el Mal de Río Cuarto virus (MRCV) transmitido por Delphacodes kuscheli. Se reportan los resultados de un estudio de las alteraciones citopatológicas producidas por el MRCV en maíz (Zea mays), trigo (Triticum aestivum) y cebada (Hordeum vulgare), observadas en microscopio electrónico de transmisión. Las plantas de maíz fueron inoculadas con ejemplares infectivos de $D$. kuscheli colectados en la zona endémica de la enfermedad. Para la transmisión del virus a los cereales de grano fino se utilizaron insectos criados en laboratorio, siendo la fuente de inóculo plantas de trigo y cebada infectadas con un aislamiento del virus obtenido en Río Cuarto y mantenido en invernáculo. Se colectaron muestras de hojas con síntomas conspicuos en maíz, y en cereales de grano fino. La infección viral fue corroborada mediante DAS-

ELISA. Se encontraron viroplasmas, conteniendo partículas virales completas e incompletas y material fibrilar, en el citoplasma de las células infectadas en todas las especies. Los viriones maduros midieron entre 60 y $70 \mathrm{~nm}$ de diámetro. En trigo y cebada, los viroplasmas y partículas dispersas fueron observados sólo en el floema, mientras que en maíz también se encontraron viriones en las células de la vaina. En maíz, se detectaron partículas formando arreglos cristalinos en las células de las enaciones. Exclusivamente en las muestras de trigo, se encontraron inclusiones tubulares. Las tres especies mostraron anomalías en los cloroplastos de las células afectadas. Los resultados obtenidos ponen de manifiesto que la citopatología propia del MRCV presenta semejanzas con la de otros fijivirus y pequeñas diferencias dependiendo de la planta hospedante.
\end{abstract}

\section{INTRODUCTION}

The Mal de Rio Cuarto virus (MRCV) belongs to the Fijivirus genus, within the Reoviridae family, and its only known vector is Delphacodes kuscheli Fennah (Hemiptera: Delphacidae) (Remes Lenicov et al., 1985). MRCV has a wide range of gramineae hosts: corn (Zea mays L.), with the most economical importance, wheat (Triticum aestivum L.), oat (Avena sativa L.), barley (Hordeum vulgare L.), and sorghum [Sorghum bicolor (L.) Moench] among others (Nome et al., 1981; Rodríguez Pardina et al., 1998; Laguna et al., 2000). The main symptoms in corn are stunting, internode 
shortening, size reduction of spikes, ears and leaves, with enations as a distinctive feature (Nome et al., 1981). Symptoms in small grain cereals are stunting, a green color darker than the normal, small or twisted leaves, swelling veins and crenatures along the leaf-blade margins (Truol et al., 2001).

The mal de Río Cuarto disease was detected for the first time in the late 60s in corn crops growing in Río Cuarto County, southern Córdoba (Argentina). At present, the disease is distributed over almost all the corn growing areas in Argentina (Laguna et al., 1999; Laguna et al., 2000), producing significant economic losses, as in 1996/97 (Lenardon et al., 1998). Nome et al. (1981) proposed the viral etiology of the disease when they detected reovirus-like particles in the phloem cells of infected plants. Work has been done since then to describe the symptoms, mode of transmission, morphology of the viral particles and the number of dsRNA segments of its genome. All these features suggested a close relationship between the "mal de Río Cuarto" and the Maize rough dwarf virus (MRDV), family Reoviridae, genus Fijivirus, that occurs in Europe and East Mediterranean (Nome et al., 1981; Milne et al., 1983; Giménez Pecci et al., 1986). However, molecular probes hybridization assays showed a low homology between MRCV and MRDV, and the same occurred when cross-reaction assays were done with anti-MRCV and anti-MRDV serum, supporting the hypothesis that MRCV was a different entity (Marzachì et al., 1995; Conci, personal communications). Truol et al. (2001) experimentally transmitted the pathogen with initially virus-free insects rared in the laboratory in order to make its biological characterization.

The fijivirus cytopathology is similar among its members (Francki et al. 1985). It consists of the presence of virions in the cytoplasm of phloem cells, the occurrence of viroplasms, and, occasionally, other kind of inclusions such as crystal arrangements or tubular structures that frequently enclose viral particles inside (Brunt et al., 1996). Viroplasms formed by light and dark areas have been seen with thin fibrils of unknown nature and function. Complete particles, which can aggregate forming crystals, appear outside the viroplasms. It is common to find tubular protein structures in the cytoplasm of MRDV and Oat sterile dwarf virus (OSDV), family Reoviridae, genus Fijivivus, infected cells, among others (Francki et al., 1985). However, in the genus type Fiji disease virus (FDV), family Reoviridae, genus Fijivivus, these inclusions were found only in infected insect cells.

The objective of this work was to describe in detail, and for the first time, the cytopathological alterations produced by the MRCV in corn leaf enations and in leaves of wheat and barley with the symptoms described above.

\section{MATERIALS AND METHODS}

\section{Plant Material}

The corn plants were infected by viruliferous insects collected from grazing fields near Río Cuarto (Córdoba,
Argentina). Seven insects per plant were placed on susceptible corn cv. Semident 4 Cargill for a two-day infection period. After taking the insects off, the inoculated plants were grown under natural conditions until they showed symptoms, at least two months after they were exposed to the vectors. Samples from five different plants were taken.

For the assays with small grain cereals, a Río Cuarto isolate was used as the inoculum source. It was obtained from infected oat plants with severe enations, twisted leaves and stunting symptoms. The inoculum was kept and multiplied in wheat and barley plants, in a greenhouse, by successive vector transmission with laboratory rared insects (Truol et al., 2001). For microscopy studies, material with known MRCV susceptibility was selected: wheat cvs. ProINTA Federal and Buck Charrúa, and barley cvs. Alfa, Negra Manfredi, Uñayché and Ranquelina (Arneodo et al., 1999), infected with one insect charge per plant. Five independent replications were made for each species, using different sets of insects. The inoculated plants were grown in a greenhouse; and samples were taken in an advanced infection stage (between one and three months after being exposed to the inoculating insects), when symptoms were marked.

In all cases, serological assays (DAS ELISA) were done before including the samples to corroborate the virus occurrence (according to Clark \& Adams, 1977).

\section{Samples processing}

Leaf portions with typical virus symptoms (enations and size reduction in corn leaves; crenatures, swelling veins and dark green color in small grain ones) were fixed in a glutaraldehide/formaldehide solution. After post fixation and precontrastation in osmium and uranyl acetate, they were dehydrated in an acetone series 50, 70, 90 (15 min each) and $100 \%$ (15 min, three times), and were included in Spurr resin. A previous $18 \mathrm{~h}$ infiltration in acetone/Spurr (1/1) was done to facilitate the resin entry into the tissues (Truol, 1998). Ultrathin sections were made with a diamond knife in an RMC MT6000-XL ultramicrotome, mounted on copper grills, and contrasted with $2 \%$ uranyl acetate and Reynolds lead citrate. They were observed with a JEOL 1200 transmission electron microscope.

Different leaf portions were included in each case, and cuttings were made at different levels of the leaf. Healthy plants samples were processed as a control.

\section{RESULTS}

The infected wheat and barley leaves, and enations from corn leaves showed large amorphous viroplasms in phloem parenchyma cells cytoplasm, formed by dark and light areas. The light areas were sometimes included within the dark ones (Figure 1A). The viroplasms had no limiting membrane, and were usually larger than the cell nucleus. Complete and incomplete (empty) particles were detected within the viroplasms; also large amounts of fibrillar material were observed frequently, which sometimes surrounded small 


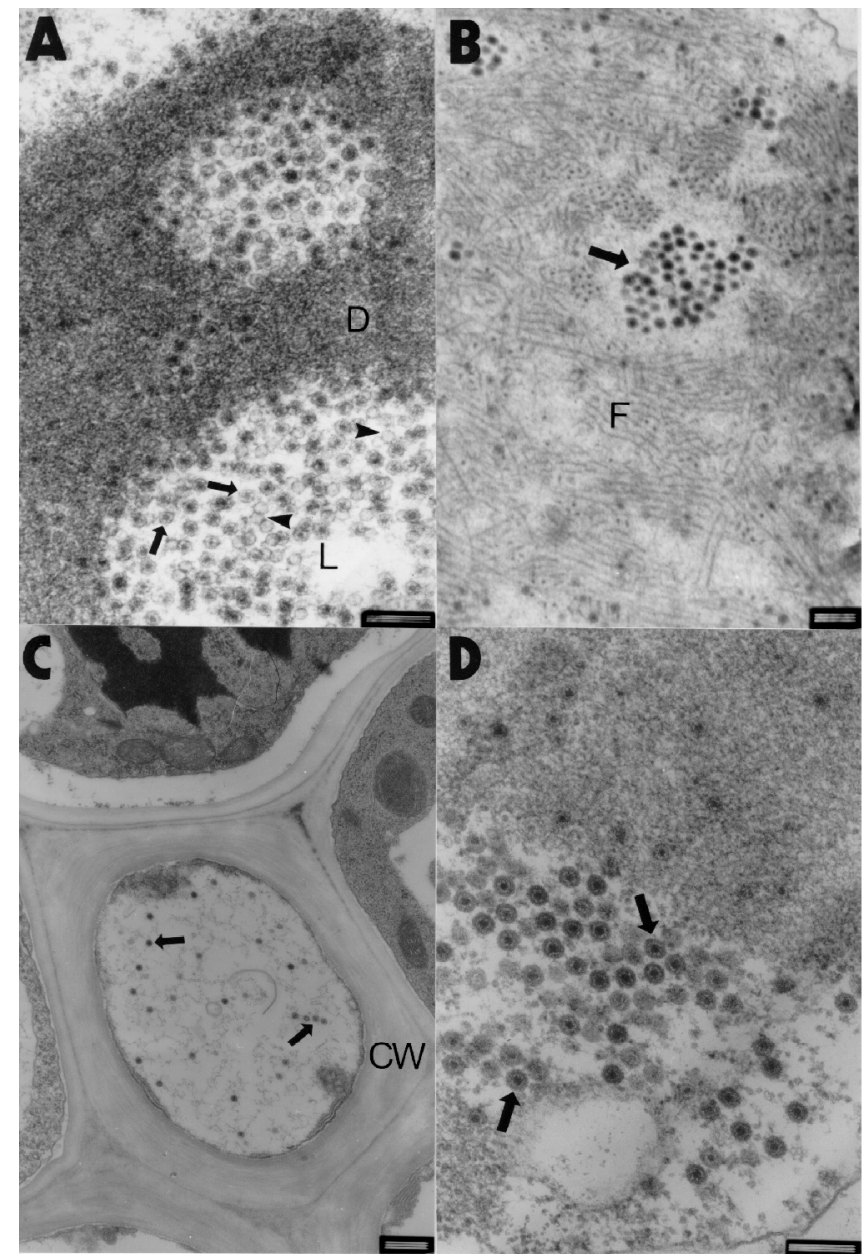

FIG. 1 - Transmission electron micrographs of thin sections from Mal de Río Cuarto virus (MRCV) infected phloem parenchyma cells of wheat (Triticum aestivum) and barley (Hordeum vulgare) leaves. (A). Viroplasm portion, with dark (D) and light (L) areas, in a MRCV infected barley cell. Complete (arrows) and incomplete (arrowheads) particles can be observed $(\mathrm{Bar}=200 \mathrm{~nm})$. (B). Fibrillar material (F) and aggregated particles (arrow) in viroplasm in a MRCV infected wheat cell $($ Bar $=200 \mathrm{~nm})$. (C). MRCV infected barley phloem cell. Free virions (arrows) in the cytoplasm are observed. $C W$ : cell wall $($ Bar $=500 \mathbf{~ n m})$. (D). Complete MRCV particles (arrows), in barley. Note the dark core inside them $(\operatorname{Bar}=200 \mathrm{~nm})$.

viral particles groups (Figure 1B). Only mature virions, which could occupy large parts of the cytoplasm reaching the cell membrane, were found outside the viroplasms. Other neighboring cells (sieve-elements or companion cells), showed variable quantities of free particles (Figure 1C). The icosaedrical virions were 60-70 $\mathrm{nm}$ diameter and had a dark core, already described by Nome et al. (1981) (Figure 1D). Virus particles were restricted to the cytoplasm in all cases, not being detected in organelles or in the nucleus of infected

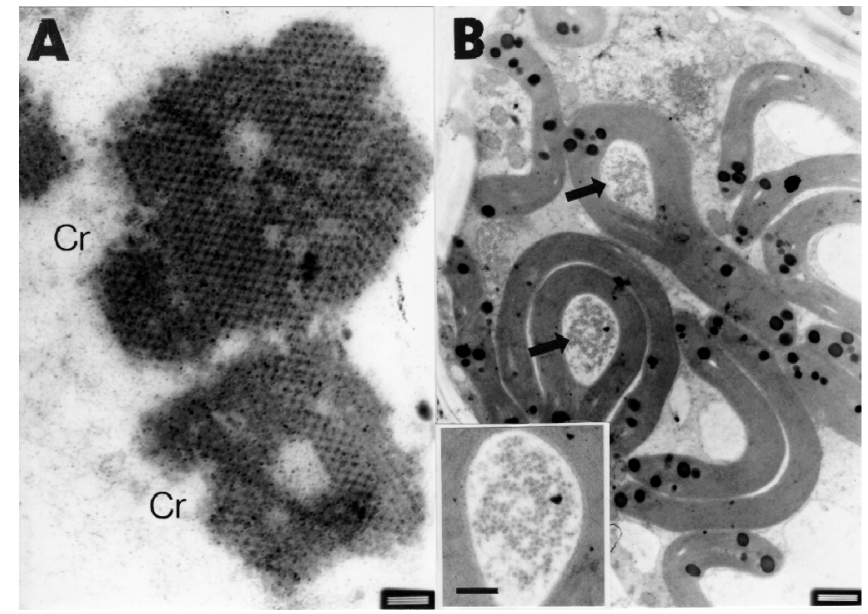

FIG. 2 - Cytopathological alterations caused by Mal de Río Cuarto virus (MRCV) in corn leaf enations. (A). Viral particles forming crystal arrangements $(\mathrm{Cr})$ in a corn (Zea mays) phloem cell $($ Bar $=200 \mathrm{~nm})$. (B). Starch chloroplasts enlarged and folded, including cytoplasm portions with viral particles (arrows), in a corn sheath cell $($ Bar $=1 \mu \mathrm{m})$. Detail bar $=500 \mathrm{~nm}$.

cells. Only in corn leaf enations viral particles were found outside the phloem, in the bundle sheath cells that surround the vascular region. In this species, crystalline arrays of particles were observed (Figure 2A). It should be emphasized that, only in the wheat cells, unbranched aligned tubules, completely closed and generally empty, between 50 and 60 $\mathrm{nm}$ diameter, occupying either large or small portions of the cytoplasm were observed (Figure 3).

The chloroplasts were the most affected organelles. In corn, wheat and barley parenchyma phloem cells, altered chloroplasts with a marked disorganization of the thylakoid system were frequently observed. In parenchyma sheath bundle and parenchyma phloem cells of corn, the starch chloroplasts were elongated and deformed, curved and folded enclosing sometimes portions of cytoplasm with viral particles (Figure 2B).

\section{DISCUSSION}

The viral particles morphology and the alterations they produce in the infected cells correspond mostly with the typical characteristics of the Fijivirus genus. The viroplasms disposition and the virions size, morphology and location, follow the usual pattern of the MRDV related viruses (Milne \& Lovisolo, 1977). It is important to highlight the presence of viral particles outside the phloem tissue in corn leaves affected with mal de Río Cuarto disease, coincidentally with Harpaz (1972) observations, who detected virions in mesophyll cells of a MRDV infected material, in ultrathin sections of corn leaves with enations. This differs with Milne \& Lovisolo (1977), who reported that only phloem and 


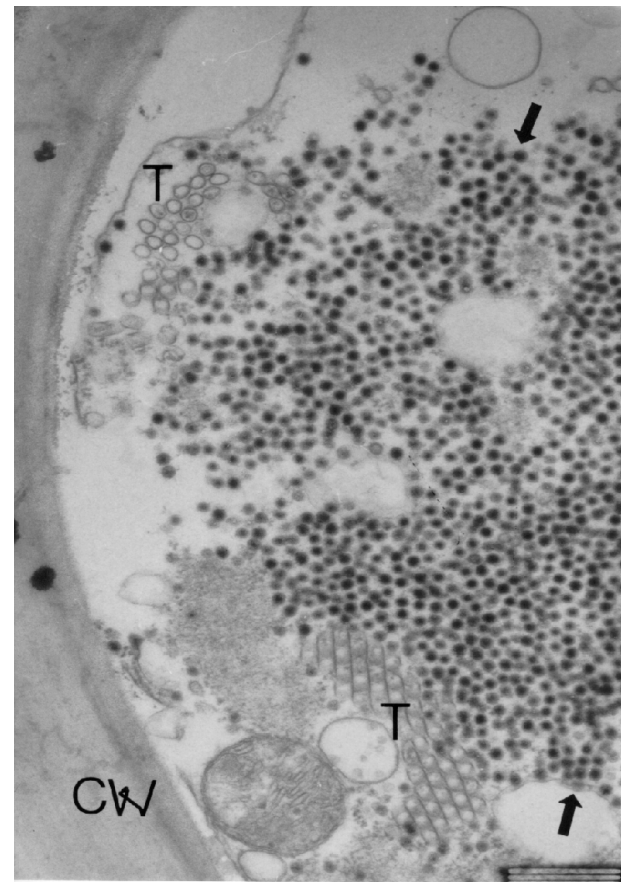

FIG. 3 - Complete particles (arrows) and tubules (T) transversally sectioned in a Mal de Río Cuarto virus (MRCV) infected wheat (Triticum aestivum $)$ cell $($ Bar $=500 \mathrm{~nm}) . \mathrm{CW}$ : cell wall.

parenchymatic phloem were invaded by the MRDV and similar viruses while the other plant tissues are particle free.

Tubules like the ones observed in MRCV infected wheat have been found in tissues infected by other members of the Reoviridae family, such as OSDV and Rice black streaked dwarf virus (RBSDV), MRDV or, within the genus Phytoreovirus, Rice dwarf virus (RDV) (Milne \& Lovisolo, 1977; Francki et al., 1985; Isogai et al. 1998). In ultrathin sections of the MRDV vector Laodelphax striatellus Fallén, Harpaz (1972) found and described tubules and fibrillar viroplasms, and he related them to different stages of the viral infection. This could be correlated to what happens in plant tissues. Although the tubules could not be detected in corn or barley samples with MRCV, its eventual presence should not be discarded. Open tubular structures like the ones of corn with RBSDV, where scrolls form often (Isogai et al., 1998) were not found in this study.

The crystals formed by viral particles that were observed in corn samples have been described in tissues infected by MRDV and related viruses (Milne \& Lovisolo, 1977). However, it was not possible to find them in wheat as described by Harpaz (1972) for MRDV.

In relation to organelles, some authors have reported parenchymatic phloem chloroplasts alterations in cereals affected by fijivirus (Gerola \& Bassi, 1965; Harpaz, 1972), as observed in MRCV infected corn.

The description of the relation of the MRCV with corn, wheat and barley cells and tissues, natural and experimentally infected, represents a contribution to the characterization of this virus.

\section{ACKNOWLEDGMENTS}

We thank Lic. Claudia Nome and Claudio Nikolaus, from INTA-IFFIVE (Córdoba, Argentina) for their constant help, advise, and support. We also thank Dr. Daniel Ducasse and Dr. Vilma Conci (INTA-IFFIVE) for their suggestions and critical review of the manuscript.

This work has been financed in part by the Instituto Nacional de Tecnología Agropecuaria (INTA, Argentina), Universidad Nacional de Río Cuarto (UNRC, Argentina), Japanese International Cooperation Agency (JICA, Japan), Consejo de Investigaciones de la Provincia de Córdoba (CONICOR, Argentina) and Fondo Nacional de Ciencia y Técnica (FONCyT, Argentina). J. Arneodo has a fellowship from the Consejo Nacional de Investigaciones Científicas y Técnicas (CONICET, Argentina).

\section{LITERATURE CITED}

ARNEODO, J., TRUOL, G. \& LAGUNA, G. Avances en la caracterización biológica del virus del mal de Río Cuarto. Fitopatología 34:172. 1999 (Abstract)

BRUNT, A.A., CRABTREE, K., DALLWITZ, M.J., GIBBS, A.J. \& WATSON, L. Viruses of Plants. CAB International. 1996.

CLARK, M.E. \& ADAMS, A.N. Characteristics of microplates methods of enzyme-linked immunosorbent assay for detection of plant viruses. Journal of General Virology 34:475-483. 1977.

FRANCKI, R.I., MILNE, R.G. \& HATTA, T. Atlas of Plant Viruses, Vol. I. CRC Press, Inc. 1985.

GEROLA F.M. \& BASSI, M. An Electron Microscopy Study of Leaf Vein Tumors From Maize Plants Experimentally Infected with Rough Dwarf Virus. Caryologia 19:13-39. 1966.

GIMÉNEZ PECCI, M.P, NOME, S.F. \& MILNE, R.G. Purificación y obtención de antisuero de las partículas del virus causal del mal de Río IV. In: II Congreso Argentino de Virología. Córdoba, Argentina. 1986.

HARPAZ, I. Maize Rough Dwarf. A planthopper virus disease affecting maize, rice, small grains and grasses. Israel University Press, Jerusalem. 1972.

ISOGAI, M., UYEDA, I. \& LEE, B.-c. Detection and assignement of proteins encoded by rice black streaked dwarf fijivirus S7, S8 and S10. Journal of General Virology 79:1487-1494. 1998.

LAGUNA, I.G., GIMÉNEZ PECCI, M.P., HERRERA, P., RODRÍGUEZ PARDINA, P., AVILA, A., \& VIRLA, E. Prospección del virus del mal de Río Cuarto en Argentina. Fitopatología 34:177. 1999. (Abstract)

LAGUNA, I.G., GIMÉNEZ PECCI, M.P., HERRERA, P.S., BORGOGNO, C., ORNAGHI, J. \& RODRÍGUEZ PARDINA, P. Rol de los cereales de invierno y verano en la epidemiología del virus del mal de Río Cuarto (Provincia de Córdoba, Argentina). Fitopatología 35:41-49. 2000.

LENARDON, S.L., MARCH, G.J., NOME, S.F. \& ORNAGHI, J.A. Recent Outbreak of "Mal de Río Cuarto Virus" on Corn in Argentina. Plant Disease 82:448. 1998.

MARZACHİ, C., BOCCARDO, G., MILNE, R., ISOGAI, M. \& 
UYEDA, I. Genome structure and variability of Fijiviruses. In: Seminars in Virology 6:103-108. 1995.

MILNE, R.G. \& LOVISOLO, O. Maize Rough Dwarf and related viruses. Advances in Virus Research 21:267-341. 1977.

MILNE, R.G., BOCCARDO, G., DAL BÓ, E. \& NOME, F. Association of maize rough dwarf virus with Mal de Río Cuarto in Argentina. Phytopathology 73:1290-1292. 1983.

NOME, S.F., LENARDON, S.L., RAJU, B.C., LAGUNA, I.G., LOWE, S.K. \& DOCAMPO, D. Association of Reovirus-like Particles with "Enfermedad de Río IV" of Maize in Argentina. Phytopathologische Zeitschrift 101:7-15. 1981.

REMES LENICOV, A.M. DE, TESON, A., DAGOBERTO, E. \& HUGUET, N. Hallazgo de uno de los vectores del mal de Río Cuarto en maíz. Gaceta Agropecuaria V:251-258. 1985 .
RODRÍGUEZ PARDINA, P.E., GIMÉNEZ PECCI, M.P., LAGUNA, I.G., DAGOBERTO, E. \& TRUOL, G. Wheat: A new natural host for the mal de Río Cuarto virus in the endemic disease area, Río Cuarto, Córdoba Province, Argentina. Plant Disease 82:149-152. 1998.

TRUOL, G. Curso básico de microscopía electrónica de transmisión aplicado a diagnóstico de enfermedades en plantas. Instituto de Fitopatología y Fisiología Vegetal (IFFIVE - INTA) y Facultad de Ciencias Exactas, Físicas y Naturales (Universidad Nacional de Córdoba). 16 al 20 de noviembre, Córdoba, Argentina. 1998.

TRUOL, G., USUGI, T., HIRAO, J., ARNEODO, J., GIMÉNEZ PECCI, M.P. \& LAGUNA, I. Transmisión experimental del virus del mal de Río Cuarto (MRCV) por Delphacodes kuscheli. Fitopatologia Brasileira 26:39-44. 2001. 